\title{
PLA2G2A wt Allele
}

National Cancer Institute

\section{Source}

National Cancer Institute. PLA2G2A wt Allele. NCI Thesaurus. Code C49363.

Human PLA2G2A wild-type allele is located within 1 p35 and is approximately $5 \mathrm{~kb}$ in length. This allele, which encodes phospholipase A2, membrane associated protein, is involved in the regulation of phospholipid metabolism in biomembranes. 